\title{
FORMATION OF STRATEGY AND TACTICS OF COMMERCIAL BANK MANAGEMENT
}

\section{ФОРМУВАННЯ СТРАТЕГІЇ І ТАКТИКИ УПРАВЛІННЯ КОМЕРЦЙНИМ БАНКОМ}

\author{
Vitalina Konenko ${ }^{1}$
}

DOI: https://doi.org/10.30525/978-9934-588-15-0-32

Abstract. The necessity to deepen theoretical ideas about the stability of the banking system and the conditions for maintaining economic equilibrium are substantiated. Integration of Ukraine into the international economic community requires the study of new research in order to create a holistic concept of stability of the banking system. The purpose of this study is to analyze methodological approaches to the formation of bank management strategies and tactics. The analysis of the interpretation and the essence of the concept of «strategy» is carried out. It is determined that in relation to the bank, strategy is the concept of long-term development, which defines the scope, means and forms of activity, the system of relationships within the organization, based on the bank's position in the market, and aimed at achieving competitive advantage. The concept of long-term development is based on the purpose of the credit institution. Historically, the goal of any commercial firm as a subject of economic activity is profit. According to the legislation, this applies to the activities of commercial banks in Ukraine. The formulation of the purpose of business is one of the most controversial aspects of business. Generalized points of view of various scientists for the purpose of development of any business in management theory. Clarified this idea of the purpose of development of a commercial bank, preferring to increase the value of the bank in the long run. The value of a bank is defined as the ability of its assets to generate income in the face of constant environmental changes. It is determined that the purpose of commercial bank development is also an integrated system of interests

\footnotetext{
${ }^{1}$ Candidate of Economic Sciences,

Lecturer of the Department of Entrepreneurship and Business Administration,

O.M. Beketov National University of Urban Economy in Kharkiv, Ukraine
}

(C) Vitalina Konenko 
of different groups. At the same time for banking business the whole set of the above goals is true: maximizing the value of the bank, keeping the balance of requirements of different stakeholders, who are users of banking products and services; maintaining a fair balance of claims of creditors and debtors of the bank; "Survival» in a changing environment. However, in this system of goals, the main point should be made to maximize the value of the bank, as it incorporates the interests of all interested parties, and the achievement of this goal allows to achieve a fair balance of requirements and «survive». It is proved that the strategy and tactics of the bank's development aimed at realization of its own interests in combination with public needs allows to create conditions for effective management and provides the basis for stable development. The presented sequence of formulation of a value-based strategy can be presented as a scheme in which the key points in the chain of support and increase of the bank's value in the long run are corporate strategy and business tactics. The competitive strategy is considered as long-term measures of offensive or defensive character, intended to strengthen the position of the enterprise, firm taking into account the intensity of competition. It is concluded that a well thought out strategy of commercial bank development is the key to its sustainable and stable development. The development strategy should be based on a system of goals, one of the main components of which is to increase the value of the bank in the long run. It is this purpose that helps to reach a compromise of interests of different groups: shareholders, managers, employees and the society as a whole, the balance of claims of debtors and creditors. It is only possible to achieve this overarching goal on the basis of a competitive strategy that seeks to achieve superiority. Competitive advantage implies a higher level of profitability than other banks. The formation of a bank's strategy should take into account the macroeconomic situation, and at each stage there must be an adequate strategy that takes into account the full range of risks inherent in each of its types. In the context of growth, preference should be given to conquest strategies.

\section{1. Ветуп}

Банківська система, будучи частиною економічної системи, займає стратегічне положення в економіці. Це визначається ії цілями, функціями, а також впливом на інші системи. Будь-який збій в іiі функціону- 
ванні зачіпає інтереси всіх господарюючих суб'єктів, кожного члена суспільства та може призвести до дестабілізації економічної, політичної, соціальної та інших сфер суспільного життя. 3 іншою боку, гармонізація грошових потоків відповідно до потреб народного господарства, управління попитом і пропозицією грошей, що досягаються за активної участі банківської системи, здатні нейтралізувати диспропорції між сукупним попитом і пропозицією в економіці.

Тенденції розвитку економіки України і динамічність функціонування ії стратегічного сектора - банківської системи - демонструють зростаючу потребу в поглибленні теоретичних уявлень про стабільність банківської системи та умови підтримки економічної рівноваги. Інтеграція України в міжнародне економічне співтовариство вимагає дослідження нових досліджень з метою створення цілісної концепції стабільності банківської системи.

Велику цінність представляють дослідження, проведені зарубіжними та вітчизняними вченими з проблем грошей, кредиту і банків в умовах ринкової економіки. Це наукові праці О.В. Дзюблюка, Р.В. Михайлюка [3], В.В. Коваленка, О.В. Крухмаля [6], В.В Маслєннікова [8] та інших. Проте недостатня розробленість цілісних уявлень про стабільність банківської системи, заходів з підтримки ії стабільності зумовило вибір теми.

Метою даного дослідження є аналіз методичних підходів до формування стратегії та тактики управління банком.

\section{2. Визначення проблем стабільного функціонування банків}

Стабільність банківської системи визначається значною мірою стабільністю іï елементів - комерційних банків. Умови стабільного розвитку банківського сектора економіки лежать в двох площинах: на макрорівні і мікрорівні. Одне з центральних місць в системі методів підтримки стабільності банківської системи та іiї цілісності на макрорівні належить нагляду за діяльністю кредитних організацій 3 боку центрального банку. У той же час слід зауважити, що нагляд не повинен обмежувати свободу функціонування елементів банківської системи. Навіть за умови обрання органами нагляду політики надмірної регламентації банківської діяльності не варто розраховувати на те, що такий підхід здатний забезпечити абсолютну безпеку і ста- 
більність банківської системи. Останнім часом все більша перевага в системі заходів банківського нагляду віддається оцінці якості управління кредитними організаціями. На це є достатньо підстав. Зокрема, управління ризиками, з якими стикаються банки на постійній основі, $\epsilon$ прерогативою менеджменту. У цій ситуації жодна, навіть дуже досконала, система оціночних показників та механізмів контролю, обрана органами нагляду для виконання своїх функцій не може і не повинна замінити менеджмент комерційного банку і не в змозі забезпечити максимальну безпеку функціонування банківської системи. 3 цього видно, що стійкість і надійність окремих кредитних організацій внаслідок неефективного менеджменту може виявитися сумнівною.

Іншими словами, навіть при наявності всіх складових умов стабільності банківської системи окремі кредитні організації виявляються, час від часу, нездатними продовжувати свій бізнес, що є підтвердженням того, що існує ще одна група проблем в області стабільності банківської системи. До числа таких проблем відноситься, перш за все, менеджмент. Однією зі складових ефективного менеджменту в кредитних організаціях є правильно обрана стратегія поведінки в постійно мінливих конкурентному середовищі.

В епоху, що передує дерегулювання фінансової сфери, проблемам стратегії, цілям і завданням управління банком, особливо на національних ринках, не приділялося належної уваги. Стратегія розвитку банку була орієнтована на внутрішні потреби, а не на ринок. 3 розвитком конкуренції та дерегуляцією різко зросла потреба у формулюванні стратегії розвитку, орієнтованої на ринкові умови господарювання.

\section{3. Аналіз трактування поняття «стратегія»}

Слово стратегія походить від грецького «стратегос», що в перекладі означає генерал. Сучасне поняття стратегії стосовно до бізнесу з'явилося в XX столітті і вперше було згадано в роботі Дж. Фон Неймана і О. Моргенштерна. Ці автори сформулювали поняття стратегії як комплекс дій компанії, сформований в відповідно до характеру певної ситуації. Інші автори пов'язують поняття стратегії з ресурсами компанії. Пізніші дослідження поняття стратегії бізнесу сформульовані більш конкретно, оскільки автори, сучасних суджень спиралися, як правило, на власний багаторічний практичний досвід роботи в най- 
більших компаніях світу. Серед таких авторів можна назвати А. Чендлера, I. Ансоффа, К. Ендрюса. По суті, зазначеною групою авторів було сформульовано класичне визначення стратегії.

Стратегія - це модель можливостей, цілей, завдань, політики і планів компанії по досягненню цих цілей, які визначають, чим компанія хоче бути в майбутньому. Видається виправданим визначення стратегії як процесу формування довгострокових цілей з урахуванням наявних можливостей і визначення напрямів досягнення цих цілей.

Стосовно до банку, стратегія - це концепція довгострокового розвитку, що визначає сферу, засоби і форми діяльності, систему взаємовідносин всередині організації, засновані на позиції банку на ринку, i спрямована на досягнення конкурентної переваги.

В основі концепції довгострокового розвитку лежить мета діяльності кредитної організації. Історично метою будь-якої комерційної фірми як суб'єкта економічної діяльності є прибуток. Відповідно до законодавства, це відноситься до діяльності комерційних банків в Україні. Формулювання мети комерційної діяльності - один 3 найбільш суперечливих аспектів бізнесу.

Протягом останніх століть ставлення до прибутку, як цілі комерційної діяльності змінювалося. Так, наприклад, в XYIII-XIX ст. використання показника прибутку для оцінки ефективності розвитку підприємств не піддавалося сумніву. Однак уже в XX ст., особливо після другої світової війни, з бурхливим розвитком технологій виникла потреба в довгострокових вкладеннях капіталу. Такий підхід вимагав концентрації уваги на довгострокових цілях розвитку. Фінансування довгострокових проектів виявилося невигідним з точки зору прибутку, однак потреба в їх здійсненні була життєво необхідною, остільки виникла необхідність в пошуку і формулюванні інших цілей розвитку. У зв'язку з цим в якості альтернативи максимізації прибутку пропонувалося використовувати чисту поточну вартість компанії, максимізацію ринкової вартості фірми, максимізацію зростання, обмеженого прибутком.

П. Драккер зруйнував традиційну трактування мети - максимізація прибутку, запропонувавши в якості альтернативи «виживання» компанії, заснованої на «функціях виживання». Прибуток, на думку цього автора, залишається в системі цілей, однак не є основною. 
У теорії менеджменту висловлювалися й інші точки зору, засновані на відповідальності перед суспільством, працівниками, акціонерами. Так, наприклад, Ф. Абрамс стверджував, що фірма зобов'язана «підтримувати справедливий баланс між вимогами різних прямо зацікавлених груп - власників акцій, працівників, покупців і публіки взагалі».

Дана точка зору виходить з того, що цілі розвитку бізнесу повинні випливати з несумісних цілей «зацікавлених груп»: менеджерів, службовців і робітників, акціонерів, постачальників, покупців. При такій постановці завдання прибуток, як результат діяльності менеджерів, показник ефективності інвестицій акціонерів, відсувався на другий план і став лише однією зі складових системи цілей компанії. Більш того, цілі менеджменту часто можуть не збігатися з цілями акціонерів банку. Менеджмент, як найманий персонал, зацікавлений в довгостроковій перспективі розвитку бізнесу, що змушує його приймати часто консервативні й обережні рішення в той час, коли виживання компанії може залежати від радикальних стратегічних заходів, таких, наприклад, як відхід від основної діяльності та диверсифікації. Власники компанії навпаки, зацікавлені в підвищенні рентабельності власних інвестицій, тобто нарощуванні прибутку.

Розбіжність інтересів різних груп призводить до виникнення конфлікту. Не випадково виникли і інші уявлення про цілі діяльності компаній. Так, наприклад, Р. Сайрт і Дж. Марч висунули тезу про те, що «організації не мають цілей, мети мають тільки люди». На їх думку мета компанії формується в результаті переговорного процесу між усіма зацікавленими групами учасників. У даній теорії вперше були об'єднані основи економічної і управлінської теорій на основі включення в процес формулювання стратегії економічних і соціальних інтересів.

Розумне поєднання економічних і соціальних інтересів різних груп, безумовно, є важливими складовими стратегії сталого розвитку. Існує багатостороння зацікавленість у поповненні банківського співтовариства фінансово стійкими кредитними організаціями, що відповідає інтересам всіх сторін. Так, наприклад, створення комерційних банків групою власників і санкціонування їх діяльності органами нагляду переслідує дві основні мети: задоволення потреб економічних суб'єктів у банківських продуктах і послугах, що $є$ відображенням їхнього суспільного призначення; дотримання інтересів власників щодо одер- 
жання доходу. При цьому органи нагляду ретельно вивчають потребу в появі нових банківських структур, а також строго стежать за тим, щоб на ринок вийшли потенційно фінансово стійкі і надійні кредитні організації. Такий інтерес переслідують, перш за все, Національний банк - відповідальний за стабільний розвиток банківської системи; акціонери і менеджмент банку, які мають конкретний економічний інтерес - отримання прибутку, а значить, розраховують на довгостроковий розвиток; споживачі банківських продуктів - клієнти, зацікавлені в отриманні дешевих і високоякісних послуг для розвитку свого бізнесу; суспільство в цілому, оскільки його добробут в певній мірі залежить від надійності і фінансової стійкості комерційних банків, здатних обслуговувати потреби економіки. Конкретним втіленням цього інтересу на різних рівнях $є$ прибуткова діяльність.

При узагальненні наведених точок зору на цілі розвитку будь-якого бізнесу в теорії менеджменту, можна помітити, що жодна з них не відкидає повністю прибуток, як позитивний результат комерційної діяльності. Прибутку приділяється лише більш-менш значуще місце в системі цілей, які визначають стратегію розвитку компаній.

При формулюванні стратегії, слід уточнити дане уявлення про мету, віддавши перевагу збільшенню вартості банку в довгостроковій перспективі. Bapmicmь банку визначається здатністю його активів проносити дохід в умовах постійних змін навколишнього середовища. Оскільки активи і зобов'язання банку генерують потоки грошових коштів, вартість банку залежить від поточної вартості майбутніх потоків готівки, дисконтованих по ставці відсотка, що відбиває ризикованість цих потоків. Вартість (дисконтований грошовий потік) відноситься до числа комплексних показників ефективності, які враховують найбільшу кількість факторів.

\section{4. Стратегія і тактика розвитку комерційного банку}

Мета розвитку комерційного банку являє собою також інтегровану систему інтересів різних груп. При цьому для банківського бізнесу справедлива вся сукупність перерахованих вище цілей: максимізація вартості банку, дотримання балансу вимог різних зацікавлених груп, які $€$ користувачами банківських продуктів і послуг; підтримання справедливого балансу вимог кредиторів і дебіторів банку; «виживання» в 
мінливому навколишньому середовищу. Однак в даній системі цілей слід виділити головну - максимізацію вартості банку, оскільки в ній закладені інтереси всіх зацікавлених сторін, а досягнення даної мети дозволяє домагатися справедливого балансу вимог i «виживати».

Стратегія і тактика розвитку банку, спрямована на реалізацію власних інтересів в поєднанні з суспільними потребами дозволяє створити умови для ефективного менеджменту і забезпечує основу стабільного розвитку.

Очевидно, що перш ніж визначити стратегію розвитку банку доцільно оцінити поточний стан бізнесу, наприклад, провести аналіз ринку акцій банку, оскільки коливання вартості акцій є об'єктивним і незалежним відображенням ринкової вартості кредитної організації, а потім зосередити свою увагу на аналізі вартості банку з урахуванням внутрішніх джерел інформації. У тих випадках, коли акції банку не котируються на біржі, що є особливістю банківської системи України, слід віддати перевагу аналізу прибутковості і рентабельності банку. Оцінка вартості банку як бізнесу на основі внутрішніх джерел інформації є складною методологічною проблемою.

На основі оцінки поточної ситуації та виявлення вартості банку на конкретний момент часу проводиться робота з розробки корпоративної стратегії, складовими елементами якої є: управління діяльністю, планування і контроль.

Схематично послідовність формулювання стратегії на основі вартості можна представити у

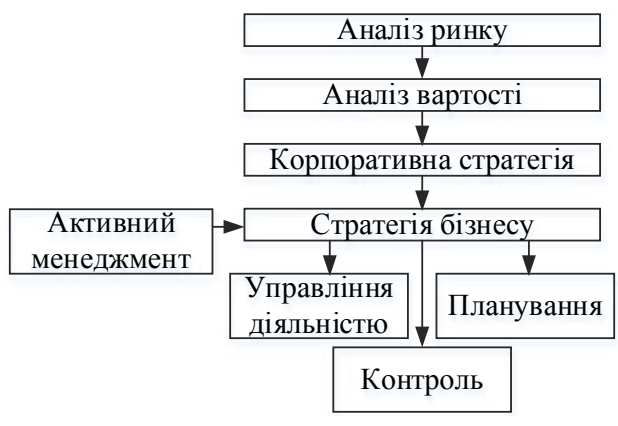

Рис. 1. Етапи вироблення стратегії банку, оріснтованої на вартість вигляді такої схеми (рис. 1).

Як видно зі схеми, ключовими моментами в ланцюжку підтримки і збільшення вартості банку в довгостроковій перспективі $є$ корпоративна стратегія і тактика бізнесу.

Корпоративна стратегія, як правило, розкриває бачення власниками банку можливостей i перспектив розвитку в різних сферах 
діяльності, які дозволять диверсифікувати активи за рахунок нових видів продуктів і послуг, в тому числі небанківського характеру (в рамках дозволених законом), проникнення на нові ринки, в тому числі міжнародні, а також за рахунок вертикальної інтеграції [10]. Результатом реалізації корпоративної стратегії може стати глобалізація бізнесу.

Стратегія бізнесу - це комплекс стратегічних цілей, завдань і заходів щодо їх реалізації в банківському середовищі. Корпоративна стратегія і тактика бізнесу являє собою лише каркас, на який нанизуються конкретні завдання і процедури їх вирішення. При цьому слід розмежовувати стратегію та політику банку.

Політика - це курс, якого дотримується банк. Її основною рисою $є$ «виваженість суджень в управлінні справами і процедурами» в потрібному для стратегії напрямку [1]. Іншими словами, політика включає комплекс заходів, спрямованих на досягнення конкретних цілей, сформульованих в стратегії. У зв'язку з цим політика більш вузьке поняття, ніж стратегія.

Реалістичність і успіх реалізації стратегії розвитку банку визначається ії відповідністю умов навколишнього середовища і точним аналізом зовнішніх і внутрішніх загроз. Навколишнє середовище комплекс позитивних і негативних зовнішніх умов, які повинен прийняти до уваги банк при розробці стратегії [7]. Основними складовими навколишнього середовища $є$ : макроекономічна, політична і соціальна ситуація; грошово-кредитна, валютна політика; критерії та вимоги органів банківського нагляду і ряд ін.

В умовах ринкових взаємозв'язків, мінливості середовища, а також посилення конкуренції банки повинні розробляти адекватну стратегію.

\section{5. Аналіз зовнішніх та внутрішніх загроз та можливостей}

Важливою складовою стратегії є врахування можливих зовнішніх і внутрішніх загроз. Схематично система зовнішніх і внутрішніх загроз, що перешкоджають зростанню вартості банку в довгостроковій перспективі, може бути представлена наступним чином (рис. 2).

Зовнішні загрози пов'язані з загостренням конкуренції на національних і міжнародних ринках; коливаннями в рівні процентних ставок, валютних курсів, котирувань цінних паперів; мінливих потреб клієнтів у послугах; можливими змінами в регулюванні банківської системи. 


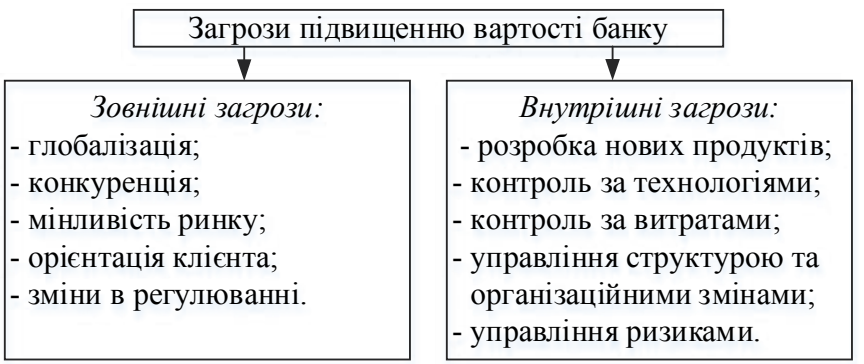

\section{Рис. 2. Зовнішні та внутрішні загрози підвищення вартості банку}

Внутрішні загрози обумовлені, в першу чергу, потребами клієнтів. Банки стикаються з необхідністю створення продуктів для конкретного клієнта, що вимагає більш жорсткого контролю з боку менеджменту за витратами. Поява нових каналів доставки інформації: інтернет, супутникова, телефонний зв'язок призводять до створення віртуальних банків, телефонних банків. Такий прогрес в області технологій пред'являє відповідні вимоги до вдосконалення структури управління банку [5].

У свою чергу зростання нестабільності на фінансових ринках вимагає нового рівня розуміння і підходів до оцінки і виміру ризиків. Виникають складні фінансові продукти. Це означає, що сучасна система моніторингу і прогнозування ризиків повинна відстежувати і вимірювати їх як на рівні банку в цілому, так і на рівні конкретних підрозділів.

Поряд 3 можливими загрозами зовнішнього і внутрішнього характеру доцільно взяти до уваги і потенційно сильні зовнішні і внутрішні можливості (рис. 3).

Зовнішні можливості можуть бути обумовлені: впровадженням на нові ринки, розширенням продуктового ряду; сприятливим становищем на ринку; вертикальною інтеграцією; обслуговуванням додаткових груп споживачів продуктів і послуг.

Внутрішні можливості відповідно: наявністю кваліфікованого персоналу в ключових областях; сприятливою структурою і обсягом ресурсів; лідерством на ринку; потенційною можливістю економії на масштабі; наявністю прогресивних технологій; перевагою в цінах на послуги; хорошою рекламою [9]. 


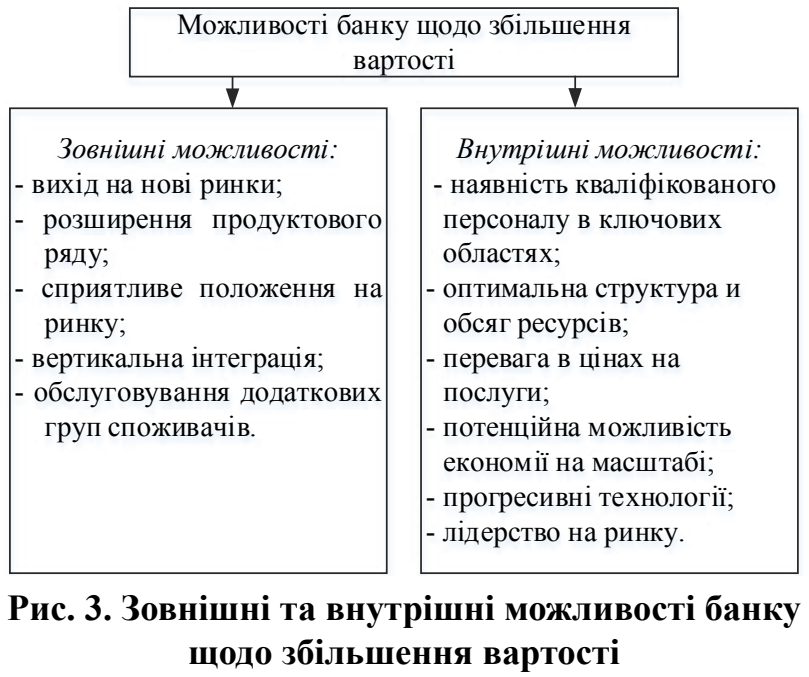

Таким чином, з урахуванням постійних змін умов зовнішнього середовища, внутрішніх загроз та можливостей при появі небезпечних тенденцій менеджмент банку повинен постійно коригувати стратегію, розглядаючи іï як продукт зовнішніх ринкових альтернатив і внутрішніх факторів. Іншими словами, приводити її у відповідність зі зміною економічної і політичної ситуації. Менеджменту банку слід брати до уваги, що на ринку діє безліч постачальників банківських продуктів, триває процес створення та виходу на ринок нових кредитних організацій, відкриваються філії зарубіжних банків на національному ринку банківських послуг, змінюються відносини між банками і клієнтами, змінюються самі клієнти, змінюється конкуренція [4]. Це означає, що в мінливому середовищі повинен змінюватися і сам банк. Розвиток навколишнього середовища вимагає від менеджменту вивчення очікувань споживачів банківських послуг і продуктів, їх потенціалу. Концепція розвитку стійкого банку вимагає ретельного відстеження та оцінки позиції конкурентів. Такий підхід впливає на вибір стратегії розвитку банку, яка повинна носити конкурентний характер. Щоб вижити і досягти успіху в бізнесі, банки повинні дотримуватися агресивної конкурентної поведінки, оскільки, тільки в цьому випадку їм вдасться відповідати мінливості попиту і різним ринковим можливостям. 


\section{6. Конкурентна стратегія банківської установи}

В економічній літературі конкурентна стратегія розглядається як довгострокові заходи наступального або оборонного характеру, покликані зміцнювати становище підприємства, фірми з урахуванням інтенсивності конкуренції [2]. Іншими словами, конкурентну стратегію можна розглядати як концепцію довгострокового розвитку, що передбачає досягнення конкурентних переваг. Виділяють декілька типів конкурентної стратегії: стратегію переваги в ціноутворенні; широті послуг, що надаються; спеціалізації за окремими видами продуктів, роботи 3 певним видом клієнтів 3 метою домогтися конкурентних переваг, зокрема, економії на витратах і максимізації прибутку. Конкурентні переваги мають, як правило, якісну і кількісну характеристики, забезпечуючи банку дохід, що перевищує середній рівень або відповідний показник конкурентів.

У процесі комерційної діяльності банки пропонують послуги для своїх клієнтів, які мають певну цінність. Цінність послуг визначається тим, скільки клієнти готові за них заплатити. Якщо вартість пропонованих послуг перевищує сукупні витрати на всю необхідну діяльність, то банк працює рентабельно.

Щоб отримати конкурентну перевагу, банк повинен надавати клієнтам послуги за ціною не вище конкурентів, однак собівартість цих послуг повинна відрізнятися меншими витратами, або надавати послуги, що мають велику цінність, за яку клієнти готові платити більш високу ціну.

Схематично створення цінності в банківській справі можна уявити наступним чином (рис. 4).

Всі види діяльності: основна і допоміжна, що входять в систему цінності, є складовими споживчої вартості банківських продуктів і послуг, тобто якісною характеристикою конкурентної переваги. Чим вище якість надаваних продуктів і послуг, тим вище цінність. При цьому основна діяльність (надання продуктів і послуг, організація контролю і управління ризиками, а також післяпродажне обслуговування клієнтів забезпечується допоміжною діяльністю (інфраструктура, забезпечення технологіями, кваліфікованими кадрами, управління ризиками). Іншими словами, представлений на рис. 4 система створення цінності, - це не просто набір окремих компонентів, а система 
Chapter «Economic sciences»

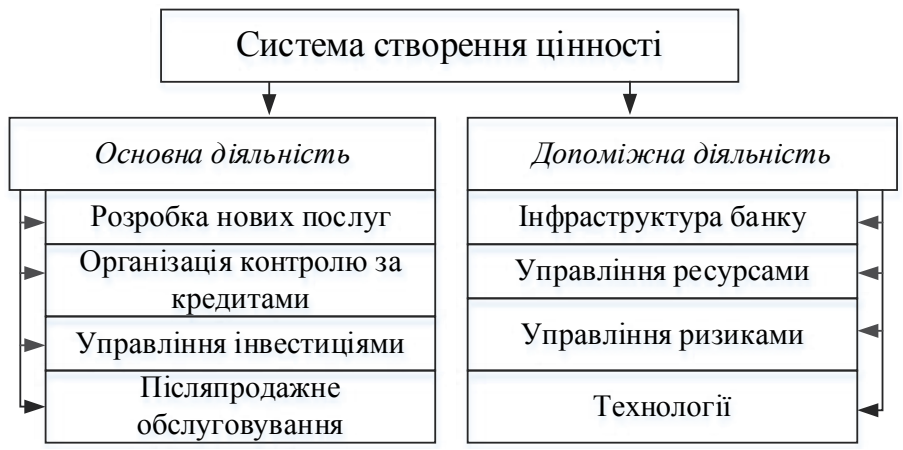

Рис. 4. Створення цінності в банківській справі

взаємопов'язаних елементів. Зміна одного з компонентів може призвести до зміни витрат на надання послуг і відбитися на рентабельності всієї діяльності, що підвищить або зведе до мінімуму конкурентну перевагу.

На перших етапах розвитку банківської системи України, відмінною рисою якої був екстенсивний фактор, основними складовими конкурентної стратегії були: переваги в ціноутворенні, спеціалізація на певних видах клієнтів і продуктів з метою максимізації прибутку. Наприклад, ряд комерційних банків одним 3 пріоритетних напрямків своєї діяльності розглядав залучення коштів у внески від фізичних осіб. При цьому акцент ставився на перевагу в ціноутворенні, що призводило до пропозиції надмірно високих відсотків за залучені кошти. Вирішуючи проблеми в області розширення ресурсної бази за рахунок агресивної процентної політики, ряд кредитних організацій не впоралися із завданням компенсації понесених витрат від розміщення залучених коштів, що призвело до збиткової діяльності, втрати фінансової стійкості і навіть банкрутства. Стратегія переваги в ціноутворенні дозволила частини кредитних організацій скласти конкуренцію Ощадному банку, однак, призвела до виникнення більш глобальної проблеми. Банки, які опинилися на межі банкрутства, були неспроможні відповідати за своїми зобов'язаннями, що призвело до вибуху обурення з боку ошуканих вкладників, які не мають будь-яких гарантій компенсацій в разі банкрутства кредитної організації. Національний 
банк був змушений ввести обмеження на обсяг залучення коштів від фізичних осіб розміром капіталу кредитної організації, обмежуючи, таким чином, розмір відповідальності власними коштами.

Іншим, найбільш поширеним видом стратегії в період екстенсивного розвитку банківської системи стала географічна експансія. На банківському небосхилі з'явилися банки з розгалуженою філіальною мережею. Стратегія таких кредитних організацій поряд зі стратегією конкуренції в ціноутворенні полягала в досягненні ефекту масштабу за рахунок зростання обсягу операцій, що дозволяло нарощувати прибуток. За рахунок економії на обсягах операцій, банки отримували додаткові можливості, конкурентні переваги в отриманні прибутку. Однак і цей тип стратегії має певні загрози, зокрема, внутрішнього характеру. Великі банки з розгалуженою філіальною мережею схильні до операційних ризиків, оскільки, чим більший банк, тим менше можливості контролю за процедурами та політичними ризиками, а значить гірше управління.

У зв'язку з цим можна виділити дві групи стратегії конкуренції: стратегію заміщення і стратегію розширення. Стратегія заміщення передбачає розширення ринкової частки за рахунок конкурентів; такий тип превалюють в умовах насичення ринку. Стратегії розширення переважно застосовуються в умовах становлення ринку, коли основні ніші вільні.

3 урахуванням загальної макроекономічної ситуації, наприклад, в умовах зростання економіки або кризи можна виділити три види стратегій: стратегію зміни, консолідації та завоювання. Класичний підхід передбачає, що в умовах кризи кредитні організації повинні віддавати перевагу стратегії зміни, в стабільній економічній ситуації - стратегії консолідації, а в умовах зростання - стратегї завоювань. При цьому стратегія повинна бути адекватна ситуації. Наприклад, в умовах зростання економіки і процвітання банківського бізнесу не виправдано формувати стратегію, спрямовану на постійне завоювання позицій на ринку. Стратегія завоювання або зростання (найчастіше географічної експансії) призведе до зниження можливостей ефективного управління, зокрема, основними ризиками, в тому числі операційними, знизить рівень контролю. Іншими словами, стратегія завоювання неминуче призведе до необхідності впровадження стратегії зміни. 
Адекватна економічному зростанню стратегія завоювання повинна поєднуватися зі стратегією консолідації, що дозволить кредитній організації закріплювати завойовані позиції на ринку на основі більш високих темпів приросту прибутку в порівнянні з ростом активів. Це дозволить привести у відповідність капітал і зобов'язання банку, зберегти рівновагу і забезпечити стабільний розвиток.

Метою стратегї̈ зміни є вироблення системи заходів з подолання кризової ситуації. При цьому менеджмент банку повинен розглянути можливості реалізації частини активів для оздоровлення балансу банку, сфокусувати увагу на видах діяльності, що приносять дохід, а також розглянути можливість скорочення накладних витрат, в тому числі за рахунок звільнення частини персоналу, скорочення або призупинення інвестицій в технології. Реалізація стратегії зміни пов'язана 3 певними ризиками. Зокрема, в умовах кризи відбувається лавиноподібне ослаблення фінансового становища кредитної організації за рахунок втрати клієнтури, звільнення найбільш кваліфікованого персоналу, зниження можливостей прийняття ефективних рішень внаслідок погіршення технологічної бази, що може привести до ризику можливого поглинання конкурентами.

Стратегія консолідації зазвичай $є$ продовженням стратегії зростання. Основними цілями стратегії консолідації є зростання прибутку і збереження частки ринку. Збільшення прибутку, в умовах стратегії консолідації, має відбуватися за рахунок зростання інвестицій в технології з метою підвищення рівня прибутковості, збільшення віддачі з боку персоналу, раціоналізації накладних витрат при жорсткому обмеженні ризиків. Збереження частки на ринку передбачає підвищення якості послуг, концентрацію уваги на постійній клієнтській базі, а також розширення кола клієнтів або кола наданих продуктів і послуг з високим рівнем прибутковості. Ризики стратегії консолідації можуть бути обумовлені агресивністю конкурентного середовища, недостатнім рівнем інвестицій і недосконалістю впроваджуваних технологій, занадто частими реорганізаціями всередині банку, надмірністю процедур і помилками, що може привести до негативних фінансових результатів, зниження мотивації персоналу, втрати командного духу.

Однією з різновидів стратегії завоювання є стратегія злиття та приєднання. Стратегія розвитку банку базується на глибокому аналізі 
позиції банку на ринку, яка, як правило, трансформується стратегію виживання і зростання. Одним з важливих моментів в зв'язку з цим, $\epsilon$ амбіції власників і менеджменту, які повинні знаходиться в кореляції 3 умовами мінливого середовища.

Стратегія може носити оборонний або наступальний характер. Рішення задач оборонного або наступального, більш агресивного характеру, притаманне стратегії злиття і поглинань. Під впливом зростаючих вимог органів нагляду, наприклад, за рівнем достатності капіталу, ліквідності, банк може вибрати стратегію злиття або поглинання.

Агресивність позиції власників банку найчастіше пов'язана з прагненням максимізації прибутку і зростання. Переваги менеджменту більш стримані i, як правило, мають такі мотиви: зміцнення іміджу, підвищення частки на ринку, досягнення ефекту масштабу і залучення висококваліфікованих кадрів. Подібного роду позиції акціонерів за умови вичерпання внутрішніх можливостей можуть стати спонукальним мотивом злиття або поглинання.

Нарешті, оборонна стратегія передбачає прийняття захисних заходів, спрямованих на зниження привабливості бізнесу для злиття або поглинання. Причин такої стратегії, як правило, декілька:

- протистояння власників розгалуження власної участі в бізнесі;

- протидія менеджменту можливій зміні свого положення в ієрархії управління.

Можливий і більш радикальний сценарій розвитку подій для власників і керівництва внаслідок поглинання - їх повне відсторонення від бізнесу.

Стратегія злиттів і поглинань або стратегія виживання і зростання вимагає дуже ретельного опрацювання, оскільки ймовірність успішного злиття або поглинання становить за оцінками фахівців лише близько $50 \%$. Причинами такого низького рівня ефекту від проведення стратегії злиття або поглинання є, як правило, наступні:

- понад оптимістична оцінка ринкового потенціалу поглинання;

- переоцінка переваг спільної діяльності;

- надмірне підвищення ціни поглинання в процесі торгів;

- невдала інтеграція після поглинання.

Оцінка результатів проведення стратегії злиття або поглинання може проводитися на попередній стадії, коли оцінюється реакція ринку 
на оголошення про злиття. Наукові дослідження в даній області показали, що акціонери виграють при поглинанні в середньому $20 \%$ премії до ціни акції при дружніх злиттях і 35\% - при ворожих поглинаннях. Інший підхід оцінки ефективності стратегії злиттів і поглинань - після закінчення операції.

Очевидно, що більшу ймовірність по досягненню успіху мають фінансово стійкі організації, які поглинають більш дрібні компанії. Під малою компанією зазвичай розуміють компанію, ціна покупки якої становить менше 10\% ринкової вартості поглинаючої компанії. Ціна результату такої інтеграції виявляється, безумовно, нижче, а шанси на успіх істотно вище. Статистичні дані та наукові дослідження в області злиттів і поглинань свідчать про те, що більш активно і успішно протікають ці процеси при горизонтальній і частково вертикальній інтеграції, коли об'єктом об'єднань стають суміжні сфери бізнесу.

3 огляду на негативні дані про успішні злиття і поглинання, стратегія в даній області має бути ретельно продумана і обгрунтована відповідними розрахунками, оскільки метою таких намірів є підвищення вартості банку. Поряд з чисто технічною стороною справи, проведенням розрахунків при плануванні інтеграції слід прийняти увагу загрозам, що перешкоджають успішному завершенню процесу. Серед них можна виділити наступні:

- негативне ставлення керівництва і власників об'єкта поглинання;

- недостатнє знання і недооцінка ступеня інтеграції окремих сфер;

- відмінність корпоративних культур;

- несумісність інформаційних систем;

- протидія персоналу об'єкта поглинання.

Безумовно, передумовою успішної інтеграції $є$ повна відкритість і співпрацю з боку об'єкта поглинання. В іншому випадку виникають істотні перешкоди на шляху отримання інформації, яка є передумовою для здійснення процесу об’єднання.

При негативному відношенні керівництва і власників банку-об'єкта до здійснення угоди успіх навряд чи може бути забезпечений. Спонукальні мотиви протидії власників і керуючих нами вже відзначалися: зниження частки участі, втрата статусу. При нестачі інформації і наявності протидіючих чинників з боку засновників і менеджменту виникають серйозні труднощі на шляху вивчення об'єкта, існуючих внутріш- 
ніх загроз з боку правових питань і умовних зобов'язань. При підготовці висновку про результати інтеграції важливе значення має оцінка можливих економічних наслідків наявних зобов'язань у об'єкта поглинання, а також прийнятності та достовірності їх відображення у фінансовій звітності. При цьому дуже важливо виявити зобов'язання, за якими мають місце не тільки економічні, а й неекономічні наслідки. В даному контексті мова йде про виконання вимог по урядовим зобов'язанням, повноті сплати платежів в бюджет і відсутність кримінальної діяльності.

Суттєве значення має облік ступеня можливої інтеграції різних областей діяльності. Схематично це можна представити таким чином (рис. 5).

Як видно з рисунку, найпростіше досягти інтеграції в області маркетингу та розробки нових видів продуктів. При цьому вплив даного сектора на стратегію буде невелика. Досить просто інтегрувати систему контролю і кредитну політику, проте дана область впливає на стратегію новостворюваного банку. Нарешті, найбільш проблемними областями в процесі інтеграції є планування; управління казначейством, розробка різних систем управління, в тому числі персоналом і операціями.

\section{Сильний}

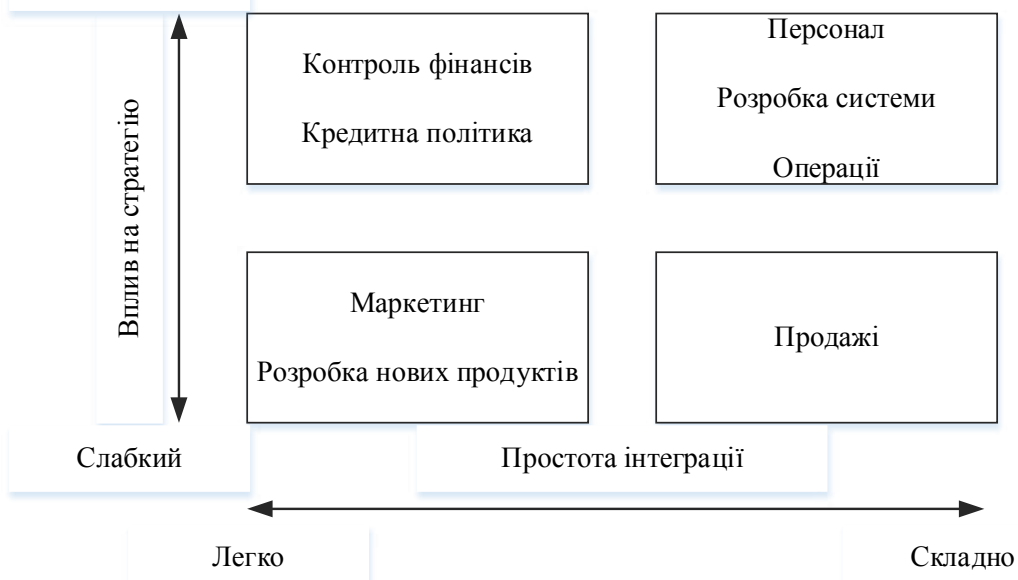

Рис. 5. Ступінь інтеграції різних областей банківської діяльності 
Важливим компонентом успішної стратегії є оцінка корпоративної культури банку-об'єкта 3 точки зору відповідності сформованої корпоративної структури банку-покупця. Недооцінка або невідповідність в принципах корпоративних культур двох банків може привести до негативних наслідків, оскільки об'єднання кадрового потенціалу $€$ невід'ємною частиною стратегії. Ключовими моментами в даному процесі слід вважати відповідність процесів і правил системи управління персоналом, наявність лояльності та відкритості персоналу, передумов для створення єдиної команди.

Важливе значення в цьому зв' язку мають такі моменти як: наявність посадових інструкцій; структура оплати праці співробітників банку-об'єкта; наявність або відсутність пільг або спеціальних програм для персоналу; потреба в перепідготовці персоналу для підвищення навичок і знань до сформованого рівня банку, який поглинається.

Ігнорування даного блоку питань може зажадати додаткових витрат і підвищити витратну частину проекту по злиттю.

Важливе значення має сумісність організаційних структур, форм власності, а також операційних та інформаційних систем 3 точки їх конвертованості. При незадовільній оцінці даного блоку проблем, слід дати їм грошову оцінку та оцінити витрати на злиття або поглинання.

Таким чином, ступінь успіху реалізації стратегії злиття або поглинання визначається не тільки сприятливими результатами прогнозу збільшення вартості банку, а й іншими не менш важливими причинами.

Основними перевагами, що досягаються при злитті або поглинанні, $\epsilon$, як правило:

- швидке досягнення темпів зростання і збільшення рівня рентабельності за рахунок збільшення обсягу операцій;

- досягнення високого рівня кваліфікації, який доповнює або перевершує рівень знань і кваліфікації персоналу;

- просування банку в число кращих серед банків країни, регіону або міста.

Однак досягнення цих переваг потребує виваженої і продуманої стратегії, підкріпленої відповідними обгрунтуваннями та оцінкою зовнішніх і внутрішніх загроз.

Реалізація стратегії завоювання, до якої відносять стратегію злиття і поглинань пов'язана з певними видами ризиків. Серед них 
можна виділити: економічні, фінансові, технічні, організаційні та ризики, пов'язані з персоналом. До економічних ризиків слід віднести спад в економіці і реакцію з боку конкурентів на оголошене рішення про злиття або поглинання. До фінансових ризиків, відповідно: зростання накладних витрат, втрату контролю над ризиками і ослаблення фінансового становища банку. Технічні ризики можуть бути обумовлені надмірним фінансуванням технологій. Внаслідок організаційних перетворень може виникати дублювання діяльності, а також неадекватність організаційної структури проведеним перетворенням. Ризики, пов'язані з персоналом обумовлені надлишковою чисельністю службовців, невідповідністю рівня кваліфікації, неузгодженістю дій, перешкодами по збереженню єдиної корпоративної культури.

\section{7. Висновки}

Чітко продумана стратегія розвитку комерційного банку є запорукою сталого і стабільного його розвитку. Під стратегією розуміють концепцію довгострокового розвитку, яка визначає сферу, засоби i форми діяльності, систему взаємовідносин всередині організації, засновані на позиції банку на ринку і спрямовані на досягнення конкурентної переваги. В основі стратегії розвитку повинна лежати система цілей, однією з головних складових яких є підвищення вартості банку в довгостроковій перспективі. Саме ця мета дозволяє досягти компромісу інтересів різних груп: акціонерів, менеджерів, співробітників і суспільства в цілому, балансу вимог дебіторів і кредиторів. Реалізувати цю головну мету можливо лише на основі конкурентної стратегії, яка передбачає досягнення переваги.

Конкурентна перевага передбачає більш високий рівень рентабельності в порівнянні з іншими банками. Формування стратегії банку має відбувається з урахуванням макроекономічної ситуації, при цьому кожному етапу повинна відповідати адекватна стратегія, що враховує весь спектр ризиків, властивих кожному їі виду. В умовах зростання перевага повинна віддаватися стратегії завоювань. Однак при орієнтації на завоювання позицій слід враховувати ризик зниження капіталу банку, в зв'язку з цим, стратегія завоювання повинна на певних етапах трансформуватися в стратегію консолідації. 


\section{Список література:}

1. Белінська Я.В., Биховченко В.П. Механізм забезпечення фінансової стабільності: структура, інструменти, напрями розвитку. Стратегічні пріоритети. 2012. № 1(22). С. 72-84.

2. Вовчак О.Д., Крамаренко О.М. Напрями стабілізації роботи банків в умовах кризових явищ. Фінансовий простір. 2014. № 4(16). С. 27-31.

3. Дзюблюк О.В., Михайлюк Р.В. Фінансова стійкість банків як основа ефективного функціонування кредитної системи: монографія. Тернопіль: Терно-Граф, 2009. 316 с.

4. Звєряков М.І., Коваленко В.В. Формування системи індикаторів фінансової стійкості банківської системи. Фінанси Украӥни. 2012. № 4. С. 3-12.

5. Коваленко В., Гаркуша Ю. Теоретичні та методичні підходи до оцінювання фінансової стабільності банківської системи. Вісник Національного банку Украӥни. 2013. № 9. С. 126-131.

6. Коваленко В.В., Крухмаль О.В. Антикризове управління в забезпеченні фінансової стійкості банківської системи : монографія. Суми : УАБС НБУ, 2007. 198 c.

7. Кочетков В.М. Організація управління фінансовою стійкістю банку в ринкових умовах: монографія. Київ : Вид-во Європ. Університету, 2003. 300 с.

8. Маслєнніков В.В. Зарубіжні банківські системи. Економіка, фінанси, право. 2010. № 10. С. 15-20.

9. Циганюк Д.Л., Гланц В.Н. Механізм забезпечення стабільності банківської системи: зарубіжний досвід та українські реалії. Вісник Української академії банківської справи. 2014. № 2. С. 40-45.

10. Шелудько Н. До визначення фінансової стійкості комерційного банку. Вісник Національного банку Украӥни. 2000. № 3. С. 40-44.

\section{References:}

1. Belinska, Ya.V., Bykhovchenko, V.P. (2012). Mekhanizm zabezpechennia finansovoi stabilnosti: struktura, instrumenty, napriamy rozvytku [The mechanism of ensuring financial stability: structure, tools, directions of development]. Stratehichni priorytety - Strategic priorities, 1(22), 72-84. (in Ukrainian)

2. Vovchak, O.D., Kramarenko, O.M. (2014). Napriamy stabilizatsii roboty bankiv v umovakh kryzovykh yavyshch [Areas of stabilization of banks in crisis conditions]. Finansovyi prostir - Financial space, 4(16), 27-31. (in Ukrainian)

3. Dziubliuk, O.V., Mykhailiuk, R.V. (2009). Finansova stiikist bankiv yak osnova efektyvnoho funktsionuvannia kredytnoi systemy [Financial stability of banks as a basis for efficient functioning of the credit system]. Ternopil: Terno-Hraf. (in Ukrainian)

4. Zvieriakov, M.I., Kovalenko, V.V. (2012). Formuvannia systemy indykatoriv finansovoi stiikosti bankivskoi systemy [Formation of system of indicators of financial stability of the banking system]. Finansy Ukrainy - Finance of Ukraine, 4, 3-12. (in Ukrainian)

5. Kovalenko, V., Harkusha, Yu. (2013). Teoretychni ta metodychni pidkhody do otsiniuvannia finansovoi stabilnosti bankivskoi systemy [Theoretical and 
methodological approaches to assessing the financial stability of the banking system]. Visnyk Natsionalnoho banku Ukrainy - Bulletin of the National Bank of Ukraine, 9, 126-131. (in Ukrainian)

6. Kovalenko, V.V., Krukhmal, O.V. (2007). Antykryzove upravlinnia v zabezpechenni finansovoi stiikosti bankivskoi systemy [Crisis management in ensuring the financial stability of the banking system]. Sumy: UABS NBU. (in Ukrainian)

7. Kochetkov, V.M. (2003). Orhanizatsiia upravlinnia finansovoiu stiikistiu banku $v$ rynkovykh umovakh [Organization of financial stability management of the bank in market conditions]. Kyiv: Vyd-vo Yevrop. Universytetu. (in Ukrainian)

8. Masliennikov, V.V. (2010). Zarubizhni bankivski systemy [Foreign banking systems]. Ekonomika, finansy, pravo - Economics, finance, law, 10, 15-20. (in Ukrainian)

9. Tsyhaniuk, D.L., Hlants, V.N. (2014). Mekhanizm zabezpechennia stabilnosti bankivskoi systemy: zarubizhnyi dosvid ta ukrainski realii [The mechanism of ensuring the stability of the banking system: foreign experience and Ukrainian realities]. Visnyk Ukrainskoi akademii bankivskoi spravy-Bulletin of the Ukrainian Academy of Banking, 2, 40-45. (in Ukrainian)

10. Sheludko, N. (2000). Do vyznachennia finansovoi stiikosti komertsiinoho banku [To determine the financial soundness of a commercial bank]. Visnyk Natsionalnoho banku Ukrainy - Bulletin of the National Bank of Ukraine, 3, 40-44. (in Ukrainian) 